\section{artelogie}

\section{Artelogie}

Recherche sur les arts, le patrimoine et la littérature de I'Amérique latine

\section{$11 \mid 2017$}

Délocalités, translocalités et activisme dans l'art électronique et biomédiale latino-américain

\title{
Video 2 - Natural History of the Enigma (2003-08).
}

Pat Badani interveiws Eduardo Kac (2)

\section{Pat Badani and Eduardo Kac}

\section{(2) OpenEdition \\ Journals}

Electronic version

URL: http://journals.openedition.org/artelogie/1660

DOI: $10.4000 /$ artelogie. 1660

ISSN: 2115-6395

\section{Publisher}

Association ESCAL

Electronic reference

Pat Badani and Eduardo Kac, « Video 2 - Natural History of the Enigma (2003-08). », Artelogie [Online] 11 | 2017, Online since, connection on 15 September 2020. URL : http://journals.openedition.org/ artelogie/1660

This text was automatically generated on 15 September 2020 .

Association ESCAL 


\section{Video 2 - Natural History of the Enigma (2003-08).}

Pat Badani interveiws Eduardo Kac (2)

Pat Badani and Eduardo Kac

This media file cannot be displayed. Please refer to the online document http:// journals.openedition.org/artelogie/1660 